\title{
Application of the CARE guideline as reporting standard in the Pharmacogenomics Research and Personalized Medicine
}

\author{
Editorial Office \\ AME Publishing Company \\ Correspondence to: Editorial Office. AME Publishing Company. Email: prpm@amegroups.com.
}

Received: 16 October 2019; Accepted: 16 October 2019.

doi: 10.21037/prpm.2019.10.01

View this article at: http://dx.doi.org/10.21037/prpm.2019.10.01

The Pharmacogenomics Research and Personalized Medicine welcomes case reports which are supposed to report new observations of diseases, clinical findings or novel/unique treatment outcomes relevant to practitioners in the fields of medicine.

For completeness and transparency for published case reports, the Pharmacogenomics Research and Personalized Medicine applies the CARE guidelines (1) as reporting standards for case reports. For any submission of case report:

(I) The author should prepare the manuscript according to the CARE guideline and indicate at the end of the Introduction section that the case report is presented in accordance with the CARE Guideline. The wording of the indication could be "We present the following case in accordance with the CARE Guideline". For the example, please refer to the article "Werthmann PG, Saltzwedel G, Kienle GS. Minor regression and long-time survival (56 months) in a patient with malignant pleural mesothelioma under Viscum album and Helleborus niger extracts—a case report" (2).

(II) The CARE Checklist (3) should be provided as an additional file. Submissions received without these elements will be returned to the authors as incomplete. The checklist will not be used as a tool for judging the suitability of manuscripts for publication, but it is intended as an aid to authors to entirely and transparently let reviewers and readers know what authors did and found.

For more detailed information, please refer to the journal's author instruction.

\section{Acknowledgments}

Funding: None.

\section{Footnote}

Provenance and Peer Review: This article was commissioned by the editorial office, Pharmacogenomics Research and Personalized Medicine. The article did not undergo external peer review.

Open Access Statement: This is an Open Access article distributed in accordance with the Creative Commons Attribution-NonCommercial-NoDerivs 4.0 International License (CC BY-NC-ND 4.0), which permits the noncommercial replication and distribution of the article with the strict proviso that no changes or edits are made and the original work is properly cited (including links to both the formal publication through the relevant DOI and the license). See: https://creativecommons.org/licenses/by-nc-nd/4.0/.

\section{References}

1. Riley DS, Barber MS, Kienle GS, et al. CARE guidelines for case reports: explanation and elaboration document. J Clin Epidemiol 2017;89:218-35.

2. Werthmann PG, Saltzwedel G, Kienle GS. Minor regression and long-time survival (56 months) in a patient with malignant pleural mesothelioma under Viscum album and Helleborus niger extracts-a case report. J Thorac Dis 2017;9:E1064-70.

3. CARE Checklist. Available online: https://cdn.amegroups. $\mathrm{cn} /$ static/public/system/application/CARE-checklistEnglish.pdf

doi: $10.21037 /$ prpm.2019.10.01

Cite this article as: Editorial Office. Application of the CARE guideline as reporting standard in the Pharmacogenomics Research and Personalized Medicine. Pharmacogenomics Res Pers Med 2019. 